\title{
Molecular Regulation of Parturition: The Role of the Decidual Clock
}

\author{
Errol R. Norwitz ${ }^{1,2}$, Elizabeth A. Bonney ${ }^{3}$, Victoria V. Snegovskikh ${ }^{4}$, Michelle A. Williams ${ }^{5}$, \\ Mark Phillippe ${ }^{6}$, Joong Shin Park ${ }^{7}$, and Vikki M. Abrahams ${ }^{8}$ \\ ${ }^{1}$ Department of Obstetrics and Gynecology, Tufts Medical Center, Boston, Massachusetts 02111 \\ ${ }^{2}$ Mother Infant Research Institute (MIRI), Tufts University School of Medicine, Boston, Massachusetts 02110 \\ ${ }^{3}$ Department of Obstetrics, Gynecology and Reproductive Sciences, University of Vermont, \\ Burlington, Vermont 05405 \\ ${ }^{4}$ Division of Reproductive Endocrinology, Department of Obstetrics and Gynecology, Women and Infants \\ Hospital of Rhode Island, Providence, Rhode Island 02905 \\ ${ }^{5}$ Department of Epidemiology, Harvard School of Public Health, Boston, Massachusetts 02115 \\ ${ }^{6}$ Vincent Center for Reproductive Biology, Department of Obstetrics and Gynecology, Massachusetts General \\ Hospital, Boston, Massachusetts 02114 \\ ${ }^{7}$ Department of Obstetrics and Gynecology, Seoul National University College of Medicine, Seoul \\ 110-799, Korea \\ ${ }^{8}$ Department of Obstetrics, Gynecology and Reproductive Sciences, Yale University School of Medicine, \\ New Haven, Connecticut 06510 \\ Correspondence: enorwitz@tuftsmedicalcenter.org
}

\begin{abstract}
The timing of birth is a critical determinant of perinatal outcome. Despite intensive research, the molecular mechanisms responsible for the onset of labor both at term and preterm remain unclear. It is likely that a "parturition cascade" exists that triggers labor at term, that preterm labor results from mechanisms that either prematurely stimulate or short-circuit this cascade, and that these mechanisms involve the activation of proinflammatory pathways within the uterus. It has long been postulated that the fetoplacental unit is in control of the timing of birth through a "placental clock." We suggest that it is not a placental clock that regulates the timing of birth, but rather a "decidual clock." Here, we review the evidence in support of the endometrium/decidua as the organ primarily responsible for the timing of birth and discuss the molecular mechanisms that prime this decidual clock.
\end{abstract}

he timely onset of labor and birth is a critical determinant of perinatal outcome. Both preterm birth (defined as delivery before 37$0 / 7 \mathrm{wk}$ of gestation) and postterm pregnancy (failure to deliver before $42-0 / 7 \mathrm{wk}$ ) are associated with an increased risk of adverse preg- nancy events. Despite intensive research, the molecular mechanisms responsible for the onset of labor both at term and preterm remain enigmatic. This is due primarily to the lack of an adequate animal model and to the autocrine/ paracrine nature of human parturition, which

Editors: Diana W. Bianchi and Errol R. Norwitz

Additional Perspectives on Molecular Approaches to Reproductive and Newborn Medicine available

at www.perspectivesinmedicine.org

Copyright (C) 2015 Cold Spring Harbor Laboratory Press; all rights reserved; doi: 10.1101/cshperspect.a023143

Cite this article as Cold Spring Harb Perspect Med 2015;5:a023143 
E.R. Norwitz et al.

precludes direct investigation. That said, a number of central themes have become clear over the past few years: (1) That a "parturition cascade" exists that triggers spontaneous labor at term; (2) that preterm labor results from mechanisms that either prematurely stimulate or short-circuit this cascade; and (3) that these mechanisms involve the activation of proinflammatory pathways within the uterus triggered by such events as intrauterine infection, hemorrhage, excessive uterine stretch, and/or maternal or fetal stress (Norwitz et al. 1999, 2014; Challis et al. 2000; Lockwood and Kuczynski 2001; Gargano et al. 2010; Muglia and Katz 2010; Esplin 2014; Romero et al. 2014).

It has long been postulated that the fetusor more correctly the fetoplacental unit-is in control of the timing of birth through a "placental clock" (McLean et al. 1995; Sandman et al. 2006). However, the inner workings of this putative placental clock have not been elucidated despite many years of investigation. We posit that this is because investigators have been looking in the wrong place. It is not a placental clock; it is a "decidual clock." Here, we review the evidence in support of the endometrium/decidua as the organ primarily responsible for the timing of birth and discuss the molecular, cellular, and immunological mechanisms that prime or set this decidual clock.

\section{WHY DOES THE HUMAN UTERUS ONLY SUPPORT A PREGNANCY FOR NINE MONTHS?}

The human uterus exists mostly in the nonpregnant state. The normal phenotype of the myometrium is contractile. It is responsible each month for actively expelling the endometrial lining and compressing the penetrating (radial) arteries so as to minimize menstrual blood loss. During pregnancy, this contractile phenotype has to be actively suppressed to allow the uterus to expand to 500-fold of its nonpregnant size. It is now well accepted that the myometrial activity that characterizes labor at term results primarily from withdrawal of mechanisms responsible for maintaining uterine quiescence (such as progesterone), with a smaller contribu- tion from factors that actively promote uterine contractility (such as oxytocin) (Norwitz et al. 2014). We suggest that this same paradigm is true also of the endometrium/decidua.

The human endometrium also exists mainly in the nonpregnant state, during which time it communicates directly with the outside environment. Despite the presence of protective barriers (the cervix with its protective mucus coat and the vagina with its acidic milieu and active mucosal immunity), the endometrium is exposed constantly to external stimuli, including sperm, infectious organisms, commensal bacteria, and environmental toxins. These stimuli have the ability to induce a proinflammatory response within the tissues of the endometrium. Indeed, a robust proinflammatory reaction at the site of implantation appears to be necessary for successful trophoblast invasion and placentation (Norwitz et al. 2001; Dekel et al. 2014). How is it then that microorganisms can coexist within the endometrium throughout gestation and within the maternal basal plate of the placenta in an apparent symbiotic relationship (Stout et al. 2013)? How is it that the blastocyst can survive and thrive within this potentially hostile environment?

A number of different theories exist as to how these phenomena occur. One opinion suggests that the driving force behind the apparent lack of decidual inflammation in response to intracellular organisms and the developing conceptus is active suppression. The mechanisms responsible for this active suppression are not well understood, but hormonal factors are likely involved. Levels of progesterone-named because it is the "progestational steroidal ketone" hormone of pregnancy-increase 50- to 100-fold in the maternal circulation after ovulation and act on the endometrium to facilitate the morphological changes referred to as "decidualization."

The decidualized endometrium (decidua) can be seen as a specialized stromal tissue that encapsulates and protects the fetoplacental unit throughout pregnancy with intrinsic and specific immunological and endocrine functions. It is comprised of endogenous decidual stromal cells as well as a variety of maternal immune cells, many of which track in from the bone 
marrow and are present in concentrations that vary in a predictable pattern throughout gestation (Vince et al. 1990; Du and Taylor 2007). The function of these cells depends on their hormonal milieu. Acting through an interleukin-8 (IL-8)-dependent mechanism, progesterone induces an influx of polymorphonuclear leukocytes into the endometrium beginning during the secretory phase of the menstrual cycle. Estriol-17 $\beta$ may suppress the inflammatory function of these cells (Abrahams et al. 2003). At the end of the menstrual cycle when estriol$17 \beta$ levels decrease, however, these cells induce inflammation through the release of reactive oxygen species to contribute to the tissue breakdown associated with menstruation (Evans and Salamonsen 2012). Similarly, endometrial macrophages, dendritic cells, T regulatory cells (Tregs), and NK cells increase in numbers during the proliferative phase in preparation for implantation of the blastocyst (Shaw et al. 2011; Mor and Abrahams 2013; Saito et al. 2013). In the nonpregnant state, high levels of innate immunity also exist within the endometrium in the form of secreted antimicrobials and IgA from the mucosal surface (Hickey et al. 2011; Wira et al. 2011). This mucosal immune function is maintained in the decidua throughout pregnancy (Gurevich et al. 2003; King et al. 2007). Other factors, such as seminal fluid, also appear to play a role in priming the endometrial epithelium, muting the inflammatory reaction, and recruiting the necessary uterine immune cells to facilitate reproductive success (Schjenken and Robertson 2014).

An alternative point of view-referred to as the Matzinger "danger theory" (for review, see Pradeu and Cooper 2012) — suggests that intracellular organisms (including viruses and bacteria) do not incite an inflammatory response within the endometrium/decidua because they do not interfere with the normal functioning of the cells in which they live. Similarly, according to the danger theory, the conceptus does not incite an inflammatory response because its development and metabolism do not induce damage or stress signals; that is, the presence of the conceptus does not pose a threat to the surrounding maternal tissues. In this model, pro- gesterone is the primarily hormonal mediator and its dysregulation activates intermediate signaling pathways leading to decidual inflammation. No matter the point of view, the critical and novel hypothesis presented in this monograph is that the factors responsible for regulating (dampening) the immune response within the endometrium/decidua (and myometrium) are put in place early in pregnancy and have a set time limit. Stated differently, these mechanisms are strongest in early pregnancy and wane over time.

According to this developmental model, advancing gestational age is associated with a withdrawal of active suppression and/or an enhanced ability to induce inflammatory signals within the endometrium/decidua. This, in turn, promotes the production and release of a variety of biologically active inflammatory mediators (prostaglandins [PGs], cytokines, growth factors, chemokines, and reactive oxygen species) at the maternal-fetal interface leading to regular phasic uterine contractions and cervical change, the condition we refer to clinically as labor (Fig. 1). The timing of this withdrawal has been closely honed over many millions of years of human evolution to optimize the onset of labor and birth at $280 \mathrm{~d}$ ( $40 \mathrm{wk}$ ) of gestation dated from the first day of the last menstrual period to maximize offspring survival. If active anti-inflammatory mechanisms are withdrawn too soon or if the decidua is metabolically dysregulated too early in gestation, spontaneous preterm labor will ensue. Preterm labor may also result from active induction of decidual inflammation in the midtrimester of pregnancy leading to the release of these same proinflammatory mediators. In such cases, however, the inciting event is likely to be known and may well fall into one of the four well-characterized pathogenic processes: intrauterine infection (chorioamnionitis), placental abruption (which refers to a decidual hemorrhage), excessive uterine stretch (as seen in multifetal pregnancies and pregnancies complicated by polyhydramnios), and/or excessive maternal or fetal stress (likely mediated through premature activation of the fetal hypothalamic-pituitary-adrenal axis) (Fig. 2) (Lockwood and Kuczynski 2001; 
E.R. Norwitz et al.
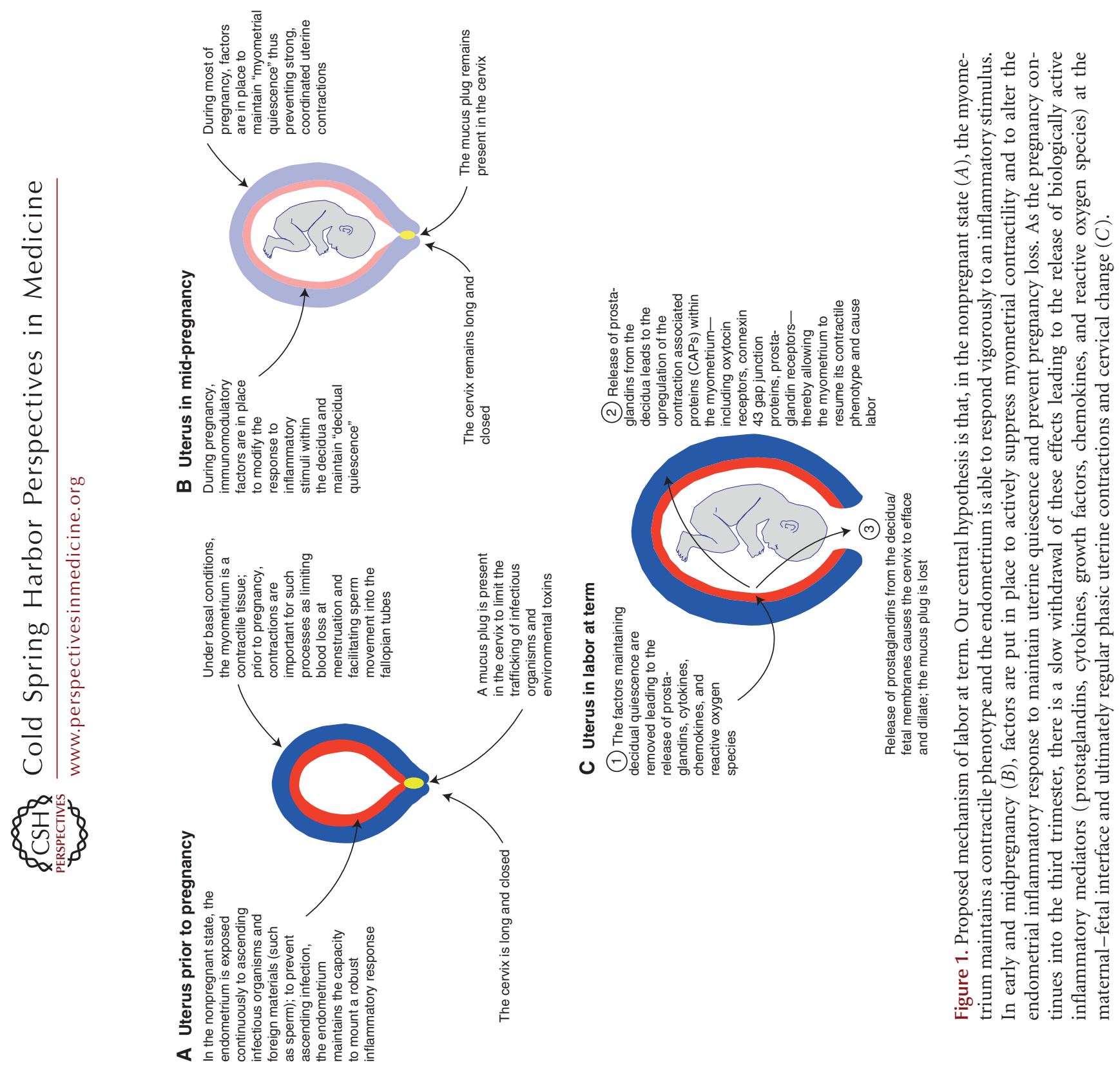
The Decidual Clock and the Timing of Birth

Gargano et al. 2010; Muglia and Katz 2010; Esplin 2014; Norwitz et al. 2014; Romero et al. 2014). A central role for another pathogenic process has recently been proposed, namely oxidative stress (Menon et al. 2014).

A new hypothesis concerning activation of the decidual clock has to do with the role of cellfree fetal DNA (cffDNA), which is released into the maternal circulation by placental apoptosis (Phillippe 2014). Circulating levels of cffDNA peak at the time of parturition, both at term (Lo et al. 1998; Ariga et al. 2001; Birch et al. 2005; Mitsunaga et al. 2010) and preterm (Farina et al. 2005; Jakobsen et al. 2012). Because it contains hypomethylated CpG motifs, cffDNA has the capacity to activate toll-like receptor-9 (TLR9) at the maternal-fetal interface, leading to the release of proinflammatory mediators (Scharfe-Nugent et al. 2012). Indeed, administration of TLR9 agonists can induce preterm labor in mice, a mechanism that appears to be actively suppressed throughout pregnancy by IL-10 (Thaxton et al. 2009; Sun et al. 2013).
Whether this mechanism is active also in humans remains to be confirmed.

An active role for the decidua in the molecular mechanisms responsible for parturition, both at term and preterm, is not an entirely novel concept. As far back as the 1980s, Drs. Paul MacDonald and M. Lynette Casey proposed that "decidual activation" was a critical element required for labor in humans (Casey and MacDonald 1988; MacDonald et al. 1991). In an opinion piece published in 2001 in Medical Hypothesis, Dr. Neil Sebire coined the term "choriodecidual inflammatory syndrome" (CoDIS) in an effort to ". . . provide a better understanding of the underlying pathophysiology that currently uses terminology which overemphasizes the importance of overt intra-amniotic infection as opposed to localized extra-amniotic inflammation which stimulates uterine evacuation" (Sebire 2001). We propose that "decidual reactivation" (or more correctly a withdrawal of decidual active suppression) is not simply a consequence of labor, but is the primary inciting

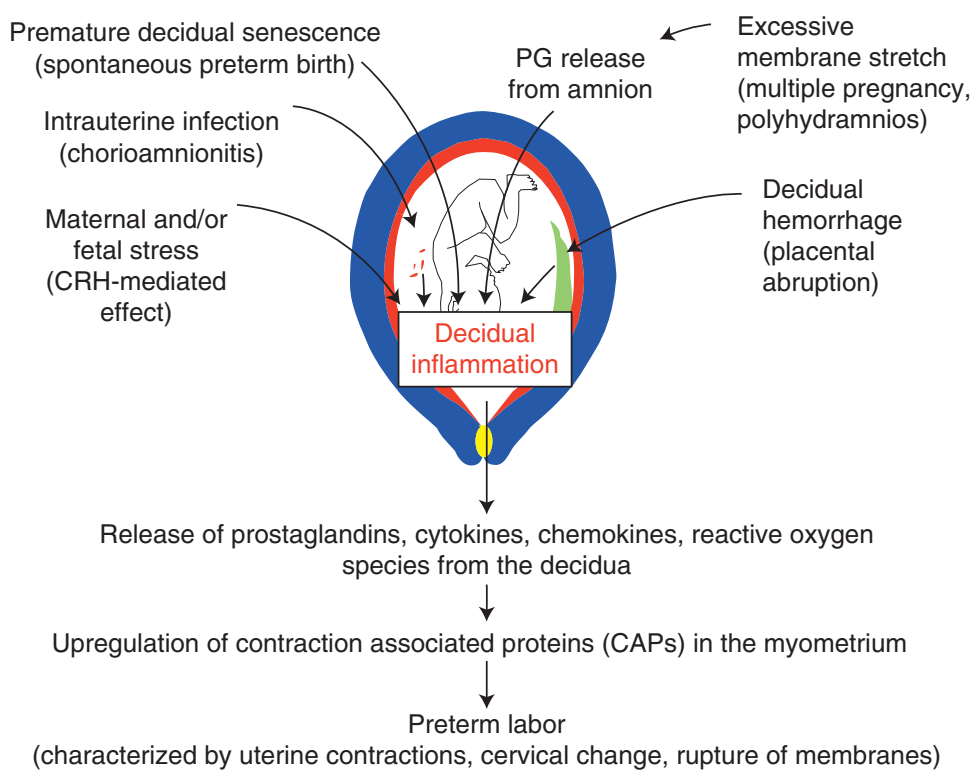

Figure 2. Proposed molecular mechanisms underlying preterm labor. The five major molecular mechanisms thought to be responsible for preterm labor and birth are shown. All converge on a single common pathway (namely, decidual inflammation) with the release of biologically active inflammatory mediators (prostaglandins [PG], cytokines, growth factors, and chemokines) at the maternal-fetal interface leading to regular phasic uterine contractions and cervical change. $\mathrm{CRH}$, corticotropin releasing hormone. 
E.R. Norwitz et al.

event in the parturition cascade, both at term and preterm.

Evidence in support of a decidual clock (and against a placental clock) is shown in Table 1 .

The concept that the decidua is an immunologically distinct tissue has been discussed for many years particularly in light of older data showing that skin grafts placed in the uterus survive far longer than those on the skin (Dodd et al. 1980), a mechanism that is mediated in part through the action of progesterone (Hansen et al. 1986). However, the presence of an endometrium/decidua is not an absolute requirement for pregnancy, and extrauterine intra-abdominal ectopic pregnancies can go to term resulting in a live birth. Interestingly, although ectopic pregnancies do not have a defined endometrium/decidua, there is an influx of unique populations of immune cells into the tissues surrounding the ectopic implantation site (Shaw et al. 2011; Shaw and Horne 2012).

The decidua is a fascinating organ from an immunological point of view. It is the maternal tissue most intimately in contact with the fetoplacental unit, with access to maternal blood on the one side and to the MHC class I-expressing extravillous trophoblast (fetal) cells that anchor the placenta to the underlying maternal decidua on the other. Blood vessels exiting the maternal vasculature pass directly through the decidua on their way to the intervillous spaces of the placenta, thereby allowing interaction between blood components and resident decidual cells. Immune cells of several types exist within the decidua (Mor and Abrahams 2013), including natural killer (NK) cells that produce cytokines; these play a critical role in vascular remodeling at the maternal-fetal interface (Zhang et al. 2011).

Under normal circumstances, the hemiallogeneic conceptus is not "rejected" by the maternal immune system. This phenomenon has long been used as a model to understand immune tolerance in other organ systems (Billingham et al. 1953; Trowsdale and Betz 2006). Classically, immunologic "tolerance" of the fetus has been explained in a number of ways, including: (1) That the maternal immune system is inherently limited in its response during pregnancy (i.e., that women are systemically immunosuppressed during pregnancy); (2) that fetal antigens are not "antigenic" and, as such, do not elicit an immune response; and (3) that there is an anatomic separation between the mother and fetus such that their immune systems do not interact in any way (Billingham et al. 1953). Recent evidence suggests that none of these assertions are true. Although the precise mechanisms responsible for this immunologic tolerance of the fetus are not clear, it is likely that several overlapping and redundant mechanisms may be involved given how critical this process is for the survival of our species.

Even before the arrival of the blastocyst, immunological priming of the endometrium may be critical for optimal implantation and placentation (Redman and Sargent 2010). Epidemiological studies have shown that women exposed to paternal antigens (i.e., sperm) from the same partner and for an extended period of time before conception (such as those who are multiparous, do not use barrier contraception, and have a long period of cohabitation or long inter-pregnancy interval before conception) have improved placentation and fewer adverse pregnancy events (Dekker et al. 1998, Dekker and Robillard 2007). In light of these and other studies in murine models, the prevailing theory is that exposure to semen promotes a state of active immune tolerance to paternal allo-antigens that facilitates maternal acceptance of the hemiallogeneic conceptus at implantation, and this effect appears to be mediated through expansion of the Treg cell pool within the endometrium (for review, see Jiang et al. 2014; Nancy and Erlebacher 2014). Treg cells, formerly known as suppressor T-cells, are a heterogeneous subpopulation of T-cells that support inherent tolerance of self-antigens (natural Tregs) and expand when challenged by bystander (anti-self) antigens to facilitate immunity to those antigens. Both seminal plasma and sperm components of semen appear to elicit the expanded Treg cell response, likely by exposing the endometrium to immune-modulating cytokines (such as TGF $\beta$ ) and male allo-antigens, respectively. In a murine model, uterine dendritic cells were capable of cross-presenting seminal fluid antigens 
The Decidual Clock and the Timing of Birth

Table 1. Evidence in support of a decidual clock for the timing of parturition

\begin{tabular}{|c|c|c|c|}
\hline \multicolumn{2}{|c|}{ Evidence } & \multirow[b]{2}{*}{$\begin{array}{l}\text { Key Points } \\
\text { The decidua is the maternal tissue most intimately in } \\
\text { contact with the feto-placental unit. } \\
\text { Immunological priming of the endometrium } \\
\text { appears to be critical to prevent rejection of the } \\
\text { hemi-allogeneic conceptus, and this effect is } \\
\text { mediated through expansion of a specific subset } \\
\text { of T-cells (Treg cells) within the endometrium. } \\
\text { Once pregnancy is established, selective epigenetic } \\
\text { silencing of key T-cell-attracting inflammatory } \\
\text { chemokine genes in decidual stromal cells appears } \\
\text { to be critical for maintaining pregnancy. }\end{array}$} & \multirow{2}{*}{$\begin{array}{l}\text { Key References } \\
\text { Redman et al. 2010; } \\
\text { Nancy et al. 2012; } \\
\text { Nancy and } \\
\text { Erlebacher, } 2014\end{array}$} \\
\hline (1) & $\begin{array}{l}\text { The decidua is an } \\
\text { immunological } \\
\text { organ distinct from } \\
\text { the placenta and } \\
\text { other maternal } \\
\text { tissues }\end{array}$ & & \\
\hline (2) & $\begin{array}{l}\text { Suppression of } \\
\text { decidual } \\
\text { prostaglandin (PG) } \\
\text { synthesis is critical } \\
\text { for pregnancy } \\
\text { success }\end{array}$ & $\begin{array}{l}\text { Endogenous levels of PGs in the decidua are 200- } \\
\text { fold lower in pregnancy than in the endometrium } \\
\text { at any stage of the menstrual cycle. } \\
\text { Failure to suppress PG production in the } \\
\text { endometrium around the time of implantation is } \\
\text { associated with spontaneous abortion. } \\
\text { The administration of exogenous PGs, by any route, } \\
\text { at any stage of gestation, and in all species } \\
\text { examined, has the ability to induce abortion. } \\
\text { Levels of PGs increase in maternal plasma, urine, } \\
\text { and amniotic fluid before the onset of uterine } \\
\text { contractions, suggesting that this PG surge is the } \\
\text { cause and not simply a consequence of labor. }\end{array}$ & $\begin{array}{l}\text { Norwitz et al. 1992; } \\
\text { Romero et al. 1996; } \\
\text { Challis et al. } 2002\end{array}$ \\
\hline (3) & $\begin{array}{l}\text { There is a genetic } \\
\text { predisposition for } \\
\text { preterm birth that is } \\
\text { carried primarily in } \\
\text { the maternal lineage }\end{array}$ & $\begin{array}{l}\text { Familial clustering, racial disparities, the high } \\
\text { incidence of recurrent preterm birth, and studies } \\
\text { in twins all suggest an important role for maternal } \\
\text { genetic factors in the timing of labor. } \\
\text { A few target maternal genes of interest have been } \\
\text { identified. } \\
\text { Epigenetic and gene-environmental factors are likely } \\
\text { also involved. }\end{array}$ & $\begin{array}{l}\text { Clausson et al. 2000; } \\
\text { Varner and Esplin, } \\
\text { 2005; Murray et al. } \\
2010\end{array}$ \\
\hline (4) & $\begin{array}{l}\text { Decidual dysregulation } \\
\text { predisposes to } \\
\text { preterm birth: the } \\
\text { two-hit hypothesis }\end{array}$ & $\begin{array}{l}\text { The final common pathway in the preterm birth } \\
\text { cascade likely involves a dysregulation (de- } \\
\text { repression) of decidual inflammation within the } \\
\text { uterus. } \\
\text { A two-hit hypothesis has been proposed in which a } \\
\text { genetic predisposition (the first hit) primes the } \\
\text { decidua for an exaggerated inflammatory } \\
\text { response to a given environmental stimulus (the } \\
\text { second hit, often an ascending infectious insult). } \\
\text { Evidence suggests that the first hit may be an } \\
\text { underlying genetic predisposition (such as a } \\
\text { genetic variant in a gene coding for a key } \\
\text { proinflammatory mediator), but may also be an } \\
\text { early infection (bacterial or viral) or an } \\
\text { underlying medical condition (PCOS, } \\
\text { endometriosis, obesity). }\end{array}$ & $\begin{array}{l}\text { Nordling, 1953; } \\
\text { Cardenas et al. } \\
\text { 2011a; Iams et al. } \\
\text { 2011; Cha et al. } \\
2013\end{array}$ \\
\hline
\end{tabular}


E.R. Norwitz et al.

to activate both $\mathrm{CD}^{+}$and $\mathrm{CD}^{+}{ }^{+}$T-cells, and mating events deficient in either sperm or seminal plasma resulted in diminished $\mathrm{CD}^{+}$, $\mathrm{CD} 25^{+}$, Foxp $3^{+}$Treg cells at the time of implantation (Robertson et al. 2009; Robertson and Moldenhauer 2014). Components of seminal fluid are also needed to prime the endometrium for the recruitment of immune (including macrophages and dendritic) cells to the implantation site (Schjenken and Robertson 2014). However, experiments involving incapacitation of the maternal systemic immune response to fetal and/or paternal antigen show that Treg cells do not provide a complete explanation of fetal tolerance.

The suggestion that fetal antigens do not elicit a maternal immune response has long ago been disproven. Indeed, immunization of the mother against fetal antigens in animal models results in a robust systemic immune response (Bonney 2001; Bonney and Onyekwuluje 2003). Moreover, evidence in humans shows that the maternal immune system can be primed to fetal antigens early in gestation and throughout the course of pregnancy to produce both cytotoxic T-cells (Bonney and Matzinger 1997; Lissauer et al. 2012) and antibodies (for review, see Parham et al. 2012).

Although fetal cells can and do leave the uterus and may thus be processed and presented by distant maternal lymph nodes, the level of systemic immunity to fetal antigens appears to be regulated primarily by the decidua. One of the major roles of the decidua, in this regard, is to limit the extent to which fetal antigens are presented to T-cells within the draining lymph nodes (i.e., to limit the extent to which the fetus is seen as antigenic) (Erlebacher et al. 2007; Bizargity et al. 2009). Exactly how this occurs is not clear. One suggestion is that the decidual immune cells themselves are poor antigen presenting cells and that, as long as the conceptus is developing normally, resident decidual dendritic ( professional antigen presenting) cells do not become activated to pick up and process fetal antigen and move to the draining node to initiate activation of naïve T-cells (Matzinger and Kamala 2011). An alternative explanation is that pregnancy itself decreases the ability of resident dendritic cells within the decidua to leave the uterus to present antigen (Tagliani and Erlebacher 2011).

The decidua shows other immunoregulatory functions as well. For example, if a potentially harmful immune response occurs in the nodes draining the uterus or in the systemic circulation, specific molecules expressed by decidual cells appear to inhibit the trafficking of effector T-cells through this tissue thereby limiting their access to the fetal cells of the placenta (Kruse et al. 1999a,b, 2002; Collins et al. 2009). The underlying mechanism appears to be a markedly reduced capacity of the CD45 ${ }^{-}$decidual stromal cells, the dominant cell population within the decidua, to produce T-cell chemoattractants during normal pregnancy (Nancy et al. 2012; Erlebacher 2013). It has long been known that T-cells are relatively scarce in the decidua (Bulmer et al. 2010), although the explanation has thus far remained unclear. Recent studies suggest that this phenomenon is due in part to selective epigenetic silencing of key T-cellattracting inflammatory chemokine genes in decidual stromal cells (Nancy et al. 2012; Erlebacher 2013). As pregnancy is established and endometrial stromal cells are transformed into decidual stromal cells under the influence of progesterone, chromatin alterations occur as evidenced by an increase in levels of the repressive histone marker, H3 trimethyl lysine 27 (H3K27me3), in the promoter regions of select proinflammatory and chemoattractant genes. The end result is a suppression that is intrinsic, gene-specific, and independent of inflammatory stimuli (Nancy et al. 2012). This same mechanism may explain the suppression in PG synthesis that occurs in the endometrium/decidua around the time of implantation (discussed below), suggesting that this effect targets not just PGs but also many other proinflammatory mediators and chemokines.

A number of other factors also appear to affect the trafficking of effector T-cells through the decidua, including cytokines (such as TGF $\beta$, IL-10, CCL2), hormones (progesterone, corticotropin-releasing hormone, PGs), Fas-Fas ligand signaling, HLA-G, Programmed Death-1 (PD-1), and other molecules that affect T-cell 
metabolism (such as tryptophan) (Bonney and Matzinger 1998; Kalantaridou et al. 2007; Xiong et al. 2010; Silasi and Mor 2012; Shepard and Bonney 2013; Nancy and Erlebacher 2014; Wu et al. 2014). Tryptophan is an essential amino required for T-cell activation. The enzyme, indoleamine 2,3-dioxygenase (IDO), degrades tryptophan through the kynurenine metabolic pathway. By producing IDO and catabolizing tryptophan at the site of implantation, the developing mammalian conceptus fails to activate an anti-fetal immune response (Munn et al. 1998). Two theories have been proposed to explain how tryptophan catabolism facilitates immune tolerance. One theory posits that tryptophan breakdown suppresses T-cell proliferation by dramatically reducing the supply of this essential amino acid. The other postulates that the downstream metabolites from tryptophan catabolism suppress immune cell function, probably through proapoptotic mechanisms (Moffett and Aryan Namboodiri 2003). Either way, it is clear that the conceptus is not merely a passenger in this process, but is actively invested in securing its own survival.

\section{SUPPRESSION OF DECIDUAL PROSTAGLANDIN SYNTHESIS IS CRITICAL FOR PREGNANCY SUCCESS}

Endogenous levels of PGs in the decidua are 200fold lower in pregnancy than in the endometrium at any stage of the menstrual cycle (Abel and Kelley 1979; Norwitz et al. 1992; Norwitz and Wilson 2000). This is true also of other uterine tissues. The prevailing evidence shows that, at least as far as the decidua is concerned, this is caused by a decrease in PG synthesis and not an increase in PG catabolism (Norwitz et al. 1992). Moreover, concentrations of unesterified (free) arachidonic acid, the precursor of the primary (biologically active) PGs and the rate-limiting step in the eicosanoid biosynthetic cascade, remain high in the decidua throughout gestation. Furthermore, the administration of exogenous PGs, by any route, at any stage of gestation, and in all species examined, has the ability to induce abortion (Embrey 1971; Casey and MacDonald
1988; Gibb 1998). Taken together, these findings support the hypothesis that pregnancy is maintained by a mechanism that tonically suppresses decidual PG synthesis throughout gestation. Indeed, failure to suppress PG production in the endometrium around the time of implantation is associated with spontaneous abortion (Jaschevatzky et al. 1983). Interestingly, one of the theories as to how intrauterine contraceptive devices (IUCDs) work is to recruit resident macrophages and T-cells from the endometrium, which then become activated and produce PGs that create a hostile proinflammatory environment within the uterus for both sperm and conceptuses (Myatt et al. 1977).

Suppression of PG production within the endometrium/decidua persists throughout most of pregnancy, and-in keeping with our overall hypothesis - withdrawal of this suppression appears to be a prerequisite for parturition. There is now overwhelming evidence that PGs are involved in the onset of labor, both at term and preterm (Norwitz et al. 1999; Challis et al. 2000), which is probably common to all mammalian viviparous species. For example, mice lacking functional $\mathrm{PGF}_{2 \alpha}$ receptors, cytosolic phospholipase $\mathrm{A}_{2}\left(\mathrm{PLA}_{2}\right)$, or $\mathrm{PGH}_{2}$ synthase type 1 (PGHS-1, also known as cyclooxygenase-1 [COX-1]), all show a delay in the onset of labor (Muglia 2000). In humans, exogenous PGs stimulate uterine contractility both in vitro and in vivo (Olson et al. 1995), and drugs that block PG synthesis can inhibit uterine contractility and prolong gestation at least for several days (King et al. 2005). Levels of PGs increase in maternal plasma, urine, and amniotic fluid before the onset of uterine contractions (Keirse and Turnbull 1973; Fuchs 1995; Romero et al. 1996), suggesting that this PG surge is the cause and not simply a consequence of labor.

All uterine tissues produce PGs and their production is carefully compartmentalized within the uterus. The fetal membranes produce almost exclusively $\mathrm{PGE}_{2}$, the decidua synthesizes mainly $\mathrm{PGF}_{2 \alpha}$ but also small amounts of $\mathrm{PGE}_{2}$ and $\mathrm{PGD}_{2}$, and the myometrium produces primarily prostacyclin $\left(\mathrm{PGI}_{2}\right)$. This is because, although these compounds are structurally similar, they can have different and often 
E.R. Norwitz et al.

antagonistic biological actions. For example, $\mathrm{PGF}_{2 \alpha}$, thromboxane, and $\mathrm{PGE}_{1}$ promote myometrial contractility by increasing calcium influx into myometrial cells and enhancing gap junction formation; whereas $\mathrm{PGD}_{2}$ and $\mathrm{PGI}_{2}$ have the opposite effects and inhibit contractions (Fuchs 1995). This compartmentalization of the primary PGs within the uterus has distinct functional implications. $\mathrm{PGE}_{2}$ is primarily of fetal origin. It is derived mainly from the fetal membranes and is rapidly degraded by the enzyme, PG dehydrogenase (PGDH), into its primary metabolite, 13,14-dihydro-15-keto- $\mathrm{PGE}_{2}$ (PGEM), which has markedly reduced biological activity. PGDH is highly expressed in the chorion. In this way, the chorion serves as a protective barrier, preventing the transfer of fetoplacental $\mathrm{PGE}_{2}$ to the underlying myometrium and thereby precluding myometrial contractions. At term, the changing hormonal milieu (increase in estrogen and cortisol; decrease in progesterone) leads to both an increase in COX expression and decrease in PGDH activity (Challis et al. 2002; Patel and Challis 2002). The resultant surge in $\mathrm{PGE}_{2}$ within the amniotic cavity at the end of pregnancy promotes cervical effacement and weakening of the fetal membranes leading to membrane rupture. A similar surge in $\mathrm{PGF}_{2 \alpha}$ occurs in the decidua. This $\mathrm{PGF}_{2 \alpha}$ then diffuses to the adjacent myometrium where it stimulates the expression of: (1) the contraction-associated protein (CAP) genes, including ion channels that promote myocyte excitability; (2) receptors for the uterotonic agonists oxytocin and the stimulatory PGs $\left(\mathrm{PGE}_{2}\right.$ and $\left.\mathrm{PGF}_{2 \alpha}\right)$; and (3) gap junction proteins (such as connexin 43) that increase the synchronization of contractions (Norwitz et al. 1999; Challis et al. 2000). Especially critical for labor is the action of oxytocin on the uterus. Levels of oxytocin in the maternal circulation remain unchanged throughout pregnancy and the first and second stages of labor. The increased sensitivity of the uterus to circulating levels of oxytocin that occurs at term is mediated instead by an increase in the number of oxytocin receptors in the myometrium (Fuchs and Fuchs 1984; Fuchs 1995; Zeeman et al. 1997). Oxytocin cannot increase its own receptor number. Rather, it acts on oxytocin receptors in the decidua to stimulate $\mathrm{PGF}_{2 \alpha}$ release, and it is this decidual $\mathrm{PGF}_{2 \alpha}$ that stimulates oxytocin receptor gene expression in the myometrium (Husslein et al. 1981; Fuchs et al. 1982). Indeed, induction of labor at term is successful only when the oxytocin infusion is associated with an increase in $\mathrm{PGF}_{2 \alpha}$ production, despite seemingly adequate uterine contractions in both induction failures and successes (Fuchs et al. 1984). Taken together, these data show that suppression of PG synthesis and release by the endometrium/decidua starting around the time of implantation and persisting to term is critical for pregnancy success.

\section{THERE IS A GENETIC PREDISPOSITION FOR PRETERM BIRTH THAT IS CARRIED PRIMARILY IN THE MATERNAL LINEAGE}

Familial clustering (Iams et al. 1998; Winkvist et al. 1998; Varner and Esplin 2005; Svensson et al. 2009), racial disparities (Blackmore et al. 1993; Carmichael et al. 1998; Ekwo and Moawad 1998; Blackmore-Prince et al. 1999; Ventura and Bachrach 2000), the high incidence of recurrent preterm birth (Mercer et al. 1999; Varner and Esplin 2005), and studies in twins (Clausson et al. 2000) all suggest an important role for maternal genetic factors in the timing of labor. Of these, the racial disparity in preterm birth risk is perhaps best documented.

Black women in the United States (including African-American, African, and Caribbean-American) have a preterm birth rate that is twofold higher than that observed in Caucasians (Blackmore et al. 1993; Carmichael et al. 1998; Ekwo and Moawad 1998; Blackmore-Prince et al. 1999; Ventura and Bachrach 2000). Even after adjusting for potential confounding demographic and behavioral variables, the rate of premature deliveries in black women remains significantly higher than that for white women, and this is especially true for spontaneous preterm birth at $20-28 \mathrm{wk}$ in which the risk is increased almost fivefold (Blackmore-Prince et al. 1999). Interestingly, one retrospective cohort analysis of $21,005,786$ singleton deliveries 
showed that interracial (black-white) couples have a risk of preterm birth that is significantly different and intermediate between that of white-white and black-black couples (Getahun et al. 2005). There is also a striking discrepancy between black and white populations in terms of recurrence risk, especially of very early preterm births. For example, in black and white women with a first delivery at 20-31 wk of gestation, the incidence of a second delivery at the same gestational age range is $13.4 \%$ and $8.2 \%$, respectively. Among black and white women who had a first delivery at $32-36 \mathrm{wk}$, the incidence of a second delivery at the same gestational age range was $3.8 \%$ and $1.9 \%$, respectively (Iams et al. 1998; Mercer et al. 1999).

However, not all black women deliver preterm. Although independently associated with preterm delivery, race/ethnicity may not be causally related to preterm birth but rather a marker of such factors as social stress, environmental exposures, and/or medical conditions that disproportionately impact women of color (Blackmore et al. 1993; Wadhwa et al. 2001; Varner and Esplin 2005; Menon et al. 2006). Data showing an independent association between race/ethnicity and pregnancy outcome suggest that genetic factors likely complicate the racial argument. Moreover, gene-environment interactions may be more important in determining whether or not the underlying genetic predisposition manifests in a clinical phenotype. For example, maternal carriers of the IL1RN*2 SNP in intron 2 of the IL-1 receptor antagonist (IL-1ra) gene show a blunted proinflammatory IL- $1 \beta$ response to abnormal vaginal flora and a lower rate of spontaneous preterm delivery (6\% vs. $18 \%, P=0.02$ ) (Genç et al. 2004a). This is true also of the $896(A>G)$ SNP in the TLR4 gene, where maternal carriers of this variant have an increase in vaginal $\mathrm{pH}, \mathrm{a}>10$-fold increase in vaginal levels of Gardnerella vaginalis and anaerobic Gram-negative rods, and an alteration in vaginal IL-1 $\beta$ and IL-1ra levels (Genç et al. 2004b). Similarly, maternal carriers of the $-308(\mathrm{G}>\mathrm{A})$ polymorphism in the promoter region of the TNF $\alpha$ gene have an increased risk of spontaneous preterm birth (OR, 2.7; 95\% CI, 1.7-4.5) (Macones et al. 2004; Genç et al. 2007), which was further increased in the presence of bacterial vaginosis (BV) (OR, 6.1; 95\% CI, 1.921.0) (Macones et al. 2004; Nguyen et al. 2004; Genç et al. 2007). Interestingly, women with this TNF $\alpha$ gene promoter polymorphism who have $\mathrm{BV}$ and who are black have an even further increased risk of spontaneous preterm birth (OR, 17) (Nguyen et al. 2004), suggesting that such factors may be additive or synergistic in their effect.

An understanding of these genetic factors may explain, at least in part, why antibiotics do not prevent preterm birth in women with preterm labor and intact membranes (Subramaniam et al. 2012; Flenady et al. 2013). Lower genital tract infections (Trichomonas vaginalis, BV) and periodontal disease are both associated with an increased risk of spontaneous preterm birth, but treatment of these disorders does not abrogate this risk (Klebanoff et al. 2001; Macones et al. 2010; Lamont et al. 2011; Boutin et al. 2013). This is because, although there is an association between such infections and preterm labor, it is not a causal association. The infecting organisms do not travel from the lower genital tract to the uterus and cause contractions. Rather, it is the underlying DNA sequences in these women, e.g., the specific variants or single nucleotide polymorphisms (SNPs) that they carry in their proinflammatory genes, which predisposes them to a number of separate inflammatory conditions, including periodontal disease, lower genital tract infections, and preterm birth. The observation that coexistence of both BV and periodontal disease do not have a synergistic effect on the risk of preterm birth (Harper et al. 2012) supports the conclusion that these are independent adverse events that are not causally related. Incidentally, broadspectrum antibiotics may also adversely affect the normal uterine microbiome, which is necessary for a healthy pregnancy (Aagaard et al. 2014).

Taken together, these data suggest an important role for maternal genetic factors in the timing of labor, both at term and preterm. Targeted and genome-wide association studies (Dolan et al. 2010; Plunkett et al. 2010, 2011; Kim et al. 2013), as well as pathway-based genetic analyses 
E.R. Norwitz et al.

(Uzun et al. 2013), have been performed in maternal-fetal dyads discordant for spontaneous preterm birth in an effort to identify specific genetic variants associated with prematurity. A number of candidate genes have been identified. One promising candidate is a variant in PLA2G4C, which codes for a specific phospholipase A isoform involved in PG biosynthesis (Plunkett et al. 2010).

Epigenetic factors have also been implicated. In one study, Brown and colleagues showed that abnormal DNA methylation in the uterine decidua (but not placenta) likely plays a role in the $\mathrm{CBA} / \mathrm{J} \times \mathrm{DBA} / 2$ murine model of pregnancy failure (Brown et al. 2013). In addition, elegantly designed ovarian transplant experiments in 15 inbred strains of mice showed a wide variation of gestation length between (but not within) strains. This variation was determined primarily by maternal genetic factors and was independent of the genetic origins of the ovary (Murray et al. 2010), thus focusing attention again on the maternal tissues of the uterus.

\section{DECIDUAL DYSREGULATION PREDISPOSES TO PRETERM BIRTH: THE TWO-HIT HYPOTHESIS}

Spontaneous preterm birth is a complex disease. It represents the final common pathway of multiple genetic, environmental, and immunological factors as well as gene-environment interactions. Environmental factors that have been implicated include maternal cigarette smoking, obesity, lower genital tract infections, and exposure to environmental toxins (Esplin 2014; Romero et al. 2014). The results of large epidemiological and genome-wide association studies designed to identify the underlying causes of spontaneous preterm birth have been largely disappointing and have led to a renewed interest in identifying the interactions between genetic susceptibility and environmental stimuli.

A murine model was recently developed with a conditional uterine deletion of $\operatorname{Tr} p 53$, a gene encoding the tumor suppressor protein $53\left(\operatorname{Trp} 53^{\operatorname{loxP} / \operatorname{loxP}} \mathrm{Pgr} \mathrm{Cre} /+\right)$, which shows a $50 \%$ incidence of spontaneous preterm birth
(Hirota et al. 2010; Cha et al. 2012). Interestingly, these preterm births occurred in the absence of systemic progesterone withdrawal, which had previously been thought to be a prerequisite for labor in this species. Further investigation showed that these mice show "premature decidual senescence" characterized by increased mTORC1 (mammalian target of rapamycin complex 1) signaling early in pregnancy. As pregnancy progresses, aberrantly high expression of the PG synthetic enzymes, COX-2 and PGF synthase, lead to a premature increase in decidual $\mathrm{PGF}_{2 \alpha}$ production and ultimately to preterm labor. mTORC1 is an intracellular protein complex that functions as a redox sensor and controls protein synthesis. Interestingly, this preterm birth phenotype could be rescued by either administration of an mTORC1 inhibitor (rapamycin) or a selective COX-2 inhibitor (celecoxib) without any apparent adverse effects on the dams or fetuses (Hirota et al. 2010, 2011). Whether such a mechanism is active in humans is unclear, although preliminary evidence suggests that this pathway may well be up-regulated in the decidua of women with spontaneous preterm birth (including an increase in mTORC1 signaling, COX-2 expression, and immunohistological staining for $\gamma \mathrm{H} 2 \mathrm{AX}$, a marker of tissue senescence and DNA damage) and can be induced in cultured human decidual stromal cells in vitro (Cha et al. 2013). Moreover, this mechanism is confined to the uterus and is independent of circulating progesterone concentrations, which is consistent with preterm birth in humans.

These same investigators then posed the following question: Knowing that the genetically engineered $\operatorname{Tr} p 53^{\operatorname{lox} P / \operatorname{lox} P} \mathrm{Pgr} C \mathrm{Cre} /+$ mice manifest premature decidual senescence with elevated levels of inflammatory mediators within the decidua leading to spontaneous preterm birth in $50 \%$ of cases, what would happen if these mice were also exposed to an exogenous inflammatory stimulus? To answer this question, they injected timed pregnant $\operatorname{Trp} 53^{\operatorname{loxP} / \operatorname{loxP} P g r} \mathrm{Cre} /+$ mice intraperitoneally with a low dose $(10 \mu \mathrm{g})$ of Toll-like receptor-4 (TLR4)-specific lipopolysaccharide (LPS) on day 16 of pregnancy and showed preterm birth and/or stillbirth in 
$100 \%$ of cases. In contrast, wild-type females showed no effect when exposed to $10 \mu \mathrm{g}$ LPS and required a dose at least fivefold higher to induce preterm birth. Moreover, treatment of the $\operatorname{Trp53} 3^{\operatorname{loxP} / \operatorname{lox} P} \mathrm{Pgr} \mathrm{Cre}^{+}+$mice with a cocktail of anti-inflammatory agents (celecoxib, progesterone, and rapamycin) was able to completely rescue the preterm birth phenotype with no apparent effect on the viability or growth of the offspring (Cha et al. 2013). These experiments provide an example of how gene-environment interactions may predispose to preterm birth. Although elegant, this model is not unique. Mice deficient for IL-10 are sensitized to lowdose bacterial- and LPS-induced preterm birth (Murphy et al. 2005; Robertson et al. 2006). Similarly, TLR4 appears to play an important role in LPS-induced preterm birth (Elovitz et al. 2003; Wang and Hirsch 2003) and blocking TLR4 function prevents high-dose LPS-induced preterm uterine contractility in nonhuman primates (Adams Waldorf et al. 2008). In all these studies, a mild inflammatory stimulus superimposed on an underlying genetic predisposition led to a dramatic clinical phenotype, which did not manifest in the absence of the genetic predisposition. Sometimes referred to as the "two-hit hypothesis" (or "multiple-hit hypothesis"), this concept was first put forward by Carl Nordling in 1953, who suggested that multiple "hits" to DNA were necessary to cause cancer (Nordling 1953).

Instead of a genetic predisposition, could an infection in early pregnancy serve as the "first hit" for preterm birth? The answer appears to be yes. Experiments in several animal model systems suggest that infection may significantly disrupt normal immune functioning within the endometrium/decidua. For example, infection with the intracellular bacterium Listeria monocytogenes blocks the pregnancy-induced $\mathrm{CD}^{+}{ }^{+}$Treg cell expansion and differentiation in the decidua that is required for pregnancy success (Xin et al. 2014). Viral infections can also increase the presence of $\mathrm{CD}^{+}{ }^{+}$and $\mathrm{CD} 8^{+}$ T-cells within the decidua (Constantin et al. 2007). In another murine model, timed pregnant $\mathrm{C} 57 \mathrm{~B} / 6$ mice infected with the murine $\gamma$ herpes virus 68 (MHV-68) (which alone does not induce inflammation or preterm birth) appears to sensitize the mother to subsequent exposure to low dose LPS (which alone has a mild or no effect on inflammation and preterm birth), leading to increased inflammation at the maternal-fetal interface and preterm delivery with fetal death in 100\% of experimental animals (Cardenas et al. 2010, 2011a). Similarly, intrauterine delivery of viral dsRNA along with bacterial peptidoglycan to pregnant mice amplifies decidual inflammation, leading to preterm delivery (Ilievski and Hirsch 2010).

Although there are reports of viral invasion of the amniotic cavity in a small proportion of women in the midtrimester (Baschat et al. 2003; Gervasi et al. 2012), the causal link between viral infection and preterm birth in humans is not yet well established. Nonetheless, the high rate of preterm birth among infected women in the most recent $\mathrm{H} 1 \mathrm{~N} 1$ influenza pandemic is intriguing (Carlson et al. 2009; Uchide et al. 2012). It has also been suggested that viral infection of the cervix during early pregnancy may reduce the capacity of the female reproductive tract to prevent ascending bacterial infection of the uterus later in gestation (Racicot et al. 2013).

The mechanism by which a subclinical viral (or bacterial) infection may prime the immune system leading to an exaggerated immunological response to a subsequent inflammatory insult is not well understood, but likely involves innate immune pattern recognition receptors and their regulators (Koga et al. 2009; Cardenas et al. 2011b). Cells of the maternal-fetal interface (trophoblast, decidual, endothelial, and fetal membranes) recognize and respond to microbes through TLRs and Nod-like receptors (NLRs) (Abrahams 2008, 2011; Hoang et al. 2014). In recent years, much attention has focused on the role of TLRs in infection-associated preterm labor. TLR4 has gained particular attention, as it is the receptor responsible for recognizing the major Gram-negative bacterial component, LPS. However, activation of TLR2 (which recognizes bacterial peptidoglycan, lipoteichoic acid, lipoproteins, and fungal zymosan), TLR3 (which senses viral dsRNA), TLR9 (which responds to bacterial CpG DNA), and 
E.R. Norwitz et al.
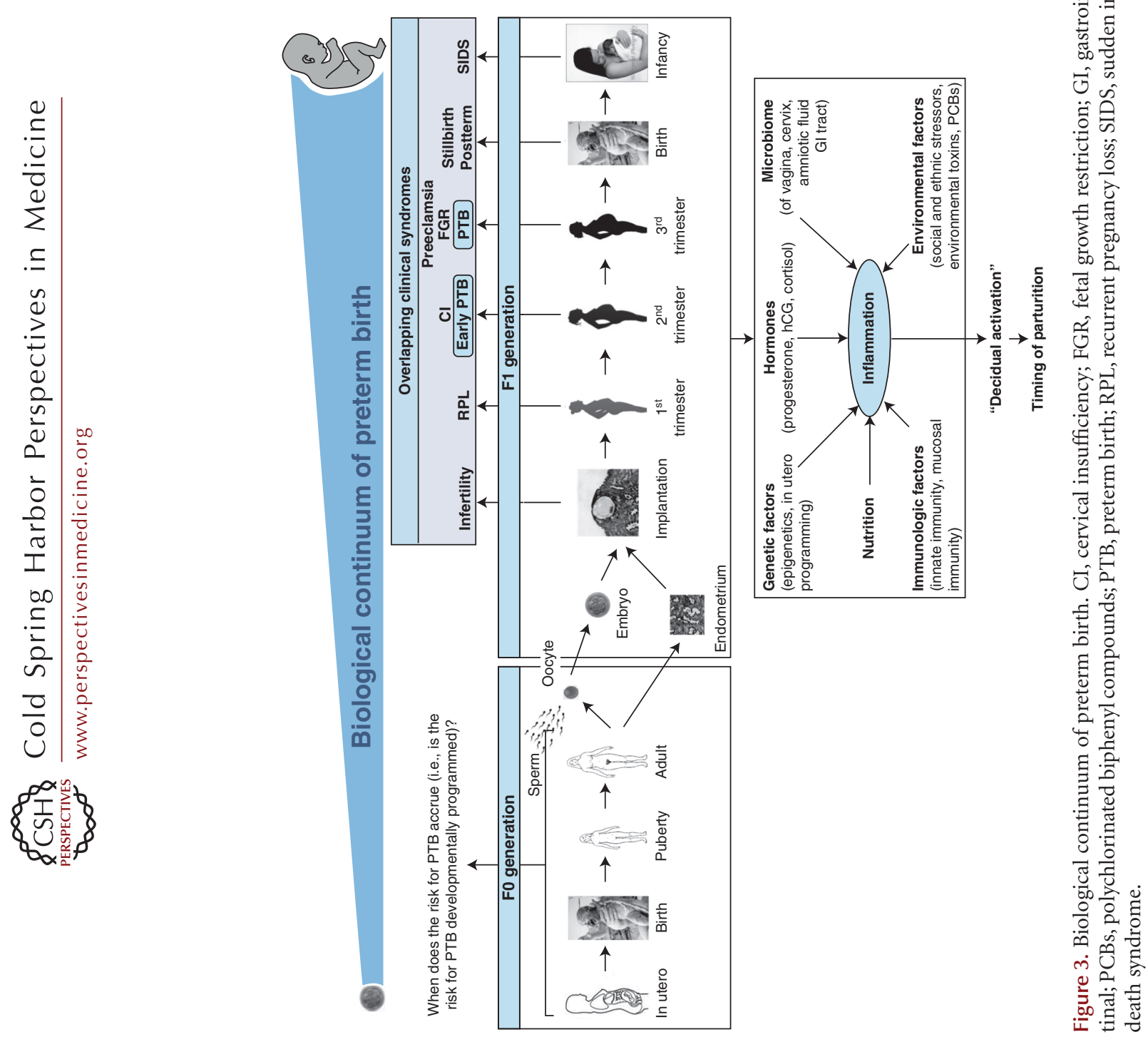
Nod1 (which senses bacterial $\gamma$-D-glutamylmeso-diaminopimelic acid [iE-DAP]) (Cardenas et al. 2011b) have also been shown to play a role in infection-associated preterm birth, although the exact site and type response varies (Koga et al. 2009; Thaxton et al. 2009). This tells us that, although some of the downstream pathways and outcomes triggered by infection through TLRs and NLRs may be similar, the upstream effector mechanisms can vary depending on the tissue involved, the infectious stimulus, and the specific innate immune receptor activated.

Finally, it has been proposed that underlying medical conditions (such as endometriosis, polycystic ovarian syndrome, and obesity) may affect the ability of progesterone to decidualize the endometrium leading to reproductive dysfunction, including infertility and preterm birth (Schulte et al. 2015). Endometriosis, a major inflammatory disease affecting women, is associated with "progesterone resistance" and downstream changes in endometrial gene expression in both ectopic and eutopic endometrium (Lessey et al. 2013). Indeed, gene expression profiling of eutopic endometrium in women with endometriosis has shown a distinct "proinflammatory profile" with dysregulation of select genes (including those involved in embryonic attachment, embryo toxicity, immune dysfunction, and apoptotic responses) leading to an inhospitable environment for implantation (Kao et al. 2003). In this way, underlying medical conditions may also serve as the first hit for preterm birth.

\section{CONCLUDING REMARKS}

Regardless of the gestational age at which it occurs, parturition is first and foremost a proinflammatory event. Our central hypothesis is that factors that are put in place around the time of blastocyst implantation tonically inhibit inflammation in the endometrium/decidua throughout gestation, but that this effect wanes over time. We posit that, as part of this developmental program, advancing gestational age is associated with a withdrawal of active suppression and/or an enhanced sensitivity of the decidua to signals capable of inducing inflammation. This promotes the release of a variety of biologically active inflammatory mediators (primarily PGs) leading to the onset of labor. If dysregulation of decidual inflammatory signaling occurs early, spontaneous preterm labor will ensue. Preterm labor may also result from active induction of decidual inflammation in the midtrimester of pregnancy due, for example, to intrauterine infection or placental abruption.

Numerous risk factors for spontaneous preterm birth in humans have been identified, including (among others) African-American ethnicity, cervical shortening, lower genital tract infection, undernutrition, anemia, and cigarette smoking. Rather than being causally related to preterm birth, there is mounting evidence to suggest that these risk factors are simply a marker of dysfunctional immunological defense within the tissues of the uterus (J Iams, pers. comm.). In the United States, preterm birth is defined as delivery between $20-0 / 7$ and 36-6/ $7 \mathrm{wk}$ of gestation. This is largely a definition of convenience. Preterm birth is not an isolated clinical condition, but is part of a continuum of adverse pregnancy events that extends throughout the length of gestation and includes subfertility, recurrent pregnancy loss, cervical insufficiency, preterm birth, and postterm pregnancy (Fig. 3) (Iams et al. 2011). The decidual clock hypothesis outlined in this monograph can be seen as a "grand unified theory" because it can explain all of these adverse pregnancy events depending on when in gestation the decidual clock is dialed down.

\section{ACKNOWLEDGMENTS}

This work was supported in part by the National Institutes of Health NIH/NICHD-sponsored Reproductive Scientist Development Program (to E.R.N.) and March of Dimes Grants (21FY05-1250 to E.R.N. and 21-FY06-574 to E.A.B.). E.A.B. is also supported by a P20 RR021905 Grant to the Vermont Center for Immunology and Infectious Disease. V.M.A. is also supported by NIH/NICHD Grants (RO1HD049446 and PO1HD054713). 
E.R. Norwitz et al.

\section{REFERENCES}

Aagaard K, Ma J, Antony KM, Ganu R, Petrosino J, Versalovic J. 2014. The placenta harbors a unique microbiome. Sci Transl Med 6: 237ra65.

Abel MH, Kelley RW. 1979. Differential production of prostaglandins within the human uterus. Prostaglandins 18: $821-828$.

Abrahams VM. 2008. Pattern recognition at the maternalfetal interface. Immunol Invest 37: 427-447.

Abrahams VM. 2011. The role of the Nod-like receptor family in trophoblast innate immune responses. J Reprod Immunol 88: 112-117.

Abrahams VM, Collins JE, Wira CR, Fanger MW, Yeaman GR. 2003. Inhibition of human polymorphonuclear cell oxidative burst by 17 - $\beta$-estradiol and 2,3,7,8-tetrachlorodibenzo-p-dioxin. Am J Reprod Immunol 50: 463-472.

Adams Waldorf KM, Persing D, Novy MJ, Sadowsky DW, Gravett MG. 2008. Pretreatment with toll-like receptor 4 antagonist inhibits lipopolysaccharide-induced preterm uterine contractility, cytokines, and prostaglandins in rhesus monkeys. Reprod Sci 15: 121-127.

Ariga H, Ohto H, Busch MP, Imamura S, Watson R, Reed W, Lee TH. 2001. Kinetics of fetal cellular and cell-free DNA in the maternal circulation during and after pregnancy: Implications for noninvasive prenatal diagnosis. Transfusion 41: 1524-1530.

Baschat AA, Towbin J, Bowles NE, Harman CR, Weiner CP. 2003. Prevalence of viral DNA in amniotic fluid of lowrisk pregnancies in the second trimester. J Matern Fetal Neonatal Med 13: 381-384.

Billingham RE, Brent L, Medawar PB. 1953. Actively acquired tolerance of foreign cells. Nature 172: 603-606.

Birch L, English CA, O’Donoghue K, Barigye O, Fisk NM, Keer JT. 2005. Accurate and robust quantification of circulating fetal and total DNA in maternal plasma from 5 to 41 weeks of gestation. Clin Chem 51: 312-320.

Bizargity P, Del Rio R, Phillippe M, Teuscher C, Bonney EA. 2009. Resistance to lipopolysaccharide-induced preterm delivery mediated by regulatory $\mathrm{T}$ cell function in mice. Biol Reprod 80: 874-881.

Blackmore CA, Ferré CD, Rowley DL, Hogue CJ, Gaiter J, Atrash H. 1993. Is race a risk factor or a risk marker for preterm delivery? Ethn Dis 3: 372-377.

Blackmore-Prince C, Kieke B Jr, Kugaraj KA, Ferré C, ElamEvans LD, Krulewitch CJ, Gaudino JA, Overpeck M. 1999. Racial differences in the patterns of singleton preterm delivery in the 1988 National Maternal and Infant Health Survey. Matern Child Health J 3: 189-197.

Bonney EA. 2001. Maternal tolerance is not critically dependent on IL-4. Immunology 103: 1-13.

Bonney EA, Matzinger P. 1997. How does the maternal immune system interact with migrating fetal cells? J Immunol 158: 40-47.

Bonney EA, Matzinger P. 1998. Much IDO about pregnancy. Nat Med 4: 1128-1129.

Bonney EA, Onyekwuluje J. 2003. The H-Y response in midgestation and long after delivery in mice primed before pregnancy. Immunol Invest 32: 71-81.

Boutin A, Demers S, Roberge S, Roy-Morency A, Chandad F, Bujold E. 2013. Treatment of periodontal disease and prevention of preterm birth: Systematic review and meta-analysis. Am J Perinatol 30: 537-544.

Brown LY, Bonney EA, Raj RS, Nielsen B, Brown S. 2013. Generalized disturbance of DNA methylation in the uterine decidua in the $\mathrm{CBA} / \mathrm{J} \times \mathrm{DBA} / 2$ mouse model of pregnancy failure. Biol Reprod 89: 120.

Bulmer JN, Williams PJ, Lash GE. 2010. Immune cells in the placental bed. Int J Dev Biol 54: 281-294.

Cardenas I, Means RE, Aldo P, Koga K, Lang SM, Booth CJ, Manzur A, Oyarzun E, Romero R, Mor G. 2010. Viral infection of the placenta leads to fetal inflammation and sensitization to bacterial products predisposing to preterm labor. J Immunol 185: 1248-1257.

Cardenas I, Mor G, Aldo P, Lang SM, Stabach P, Sharp A, Romero R, Mazaki-Tovi S, Gervasi M, Means RE. 2011a. Placental viral infection sensitizes to endotoxin-induced pre-term labor: A double hit hypothesis. Am J Reprod Immunol 65: 110-117.

Cardenas I, Mulla MJ, Myrtolli K, Sfakianaki AK, Norwitz ER, Tadesse S, Guller S, Abrahams VM. 2011b. Nod1 activation by bacterial iE-DAP induces maternal-fetal inflammation and preterm labor. J Immunol 187: 980 986.

Carlson A, Thung SF, Norwitz ER. 2009. H1N1 Influenza in pregnancy: What all obstetric care providers ought to know. Rev Obstet Gynecol 2: 139-145.

Carmichael SL, Iyasu S, Hatfield-Timajchy K. 1998. Causespecific trends in neonatal mortality among black and white infants, United States, 1980-1995. Matern Child Health J 2: 67-76.

Casey ML, MacDonald PC. 1988. Biomolecular processes in the initiation of parturition: Decidual activation. Clin Obstet Gynecol 31: 533-552.

Cha J, Sun X, Dey SK. 2012. Mechanisms of implantation: Strategies for successful pregnancy. Nat Med 18: $1754-$ 1767.

Cha J, Bartos A, Egashira M, Haraguchi H, Saito-Fujita T, Leishman E, Bradshaw H, Dey SK, Hirota Y. 2013. Combinatory approaches prevent preterm birth profoundly exacerbated by gene-environment interactions. J Clin Invest 123: 4063-4075.

Challis JRG, Matthews SG, Gibb W, Lye SJ. 2000. Endocrine and paracrine regulation of birth at term and preterm. Endocrine Rev 21: 514-550.

Challis JR, Sloboda DM, Alfaidy N, Lye SJ, Gibb W, Patel FA, Whittle WL, Newnham JP. 2002. Prostaglandins and mechanisms of preterm birth. Reproduction 124: 1-17.

Clausson B, Lichtenstein P, Cnattingius S. 2000. Genetic influence on birthweight and gestational length determined by studies in offspring of twins. Br J Obstet Gynaecol 107: 375-381.

Collins MK, Tay CS, Erlebacher A. 2009. Dendritic cell entrapment within the pregnant uterus inhibits immune surveillance of the maternal/fetal interface in mice. $J$ Clin Invest 119: 2062-2073.

Constantin CM, Masopust D, Grayson J, Stricklan OL, Ahmed R, Bonney EA. 2007. Normal establishment of virusspecific memory CD8 $\mathrm{T}$ cell pool following primary infection during pregnancy. J Immunol 179: 4383-4389. 
Dekel N, Gnainsky Y, Granot I, Racicot K, Mor G. 2014 The role of inflammation for a successful implantation. Am J Reprod Immunol 72: 141-147.

Dekker G, Robillard PY. 2007. Pre-eclampsia: Is the immune maladaptation hypothesis still standing? An epidemiological update. J Reprod Immunol 76: 8-16.

Dekker GA, Robillard PY, Hulsey TC. 1998. Immune maladaptation in the etiology of preeclampsia: A review of corroborative epidemiologic studies. Obstet Gynecol Surv 53: $377-382$.

Dodd M, Andrew TA, Coles JS. 1980. Functional behaviour of skin allografts transplanted to rabbit deciduomata. J Anat 130: 381-390.

Dolan SM, Hollegaard MV, Merialdi M, Betran AP, Allen T, Abelow C, Nace J, Lin BK, Khoury MJ, et al. 2010. Synopsis of preterm birth genetic association studies: The preterm birth genetics knowledge base (PTBGene). Public Health Genomics 13: 514-523.

Du H, Taylor HS. 2007. Contribution of bone marrow-derived stem cells to endometrium and endometriosis. Stem Cells 25: 2082-2086.

Ekwo E, Moawad A. 1998. The risk for recurrence of premature births to African-American and white women. J Assoc Acad Minor Phys 9: 16-21.

Elovitz MA, Wang Z, Chien EK, Rychlik DF, Phillippe M. 2003. A new model for inflammation-induced preterm birth: The role of platelet-activating factor and Toll-like receptor-4. Am J Pathol 163: 2103-2111.

Embrey M. 1971. PGE compounds for induction of labour and abortion. Ann NY Acad Sci 180: 518-523.

Erlebacher A. 2013. Immunology of the maternal-fetal interface. Annu Rev Immunol 31: 387-411.

Erlebacher A, Vencato D, Price KA, Zhang D, Glimcher LH. 2007. Constraints in antigen presentation severely restrict $\mathrm{T}$ cell recognition of the allogeneic fetus. J Clin Invest 117: 1399-1411.

Esplin MS. 2014. Overview of spontaneous preterm birth: A complex and multifactorial phenotype. Clin Obstet Gynecol 57: 518-530.

Evans J, Salamonsen LA. 2012. Inflammation, leukocytes and menstruation. Rev Endocr Metab Disord 13: $277-$ 288.

Farina A, LeShane ES, Romero R, Gomez R, Chaiworapongsa T, Rizzo N, Bianchi DW. 2005. High levels of fetal cell-free DNA in maternal serum: A risk factor for spontaneous preterm delivery. Am J Obstet Gynecol 193: 421 425.

Flenady V, Hawley G, Stock OM, Kenyon S, Badawi N. 2013. Prophylactic antibiotics for inhibiting preterm labour with intact membranes. Cochrane Database Syst Rev 5: 12:CD000246.

Fuchs AR. 1995. Plasma membrane receptors regulating myometrial contractility and their hormonal modulation. Semin Perinatol 19: 15-30.

Fuchs AR, Fuchs F. 1984. Endocrinology of human parturition: A review. Br J Obstet Gynaecol 91: 948-967.

Fuchs AR, Fuchs F, Husslein P, et al. 1982. Oxytocin receptors and human parturition: A dual role for oxytocin in the initiation of labor. Science 215: 1396-1398.
The Decidual Clock and the Timing of Birth

Fuchs AR, Fuchs F, Husslein P, Soloff MS. 1984. Oxytocin receptors in the human uterus during pregnancy and parturition. Am J Obstet Gynecol 150: 734-741.

Gargano JW, Holzman CB, Senagore PK, Reuss ML, Pathak DR, Williams MA, Fisher R. 2010. Evidence of placental haemorrhage and preterm delivery. Br J Obstet Gynaecol 117: 445-455.

Genç MR, Onderdonk AB, Vardhana S, Delaney ML, Norwitz ER, Tuomala RE, Paraskevas LR, Witkin SS. 2004a. Polymorphism in intron 2 of the interleukin-1 receptor antagonist gene, local mid-trimester cytokine response to vaginal flora, and subsequent preterm birth. Am J Obstet Gynecol 191: 1324-1330.

Genç MR, Vardhana S, Delaney ML, Onderdonk A, Tuomala R, Norwitz E, Witkin SS. 2004b. Relationship between a toll-like receptor-4 gene polymorphism, bacterial vaginosis-related flora and vaginal cytokine responses in pregnant women. Eur J Obstet Gynecol Reprod Biol 116: $152-156$.

Genç MR, Vardhana S, Delaney ML, Witkin SS, Onderdonk AB. MAP Study Group. 2007. TNFa -308G > A polymorphism influences the TNF- $\alpha$ response to altered vaginal flora. Eur J Obstet Gynecol Reprod Biol 134: 188-191.

Gervasi MT, Romero R, Bracalente G, Chaiworapongsa T, Erez O, Dong Z, Hassan SS, Yeo L, Yoon BH, Mor G, et al. 2012. Viral invasion of the amniotic cavity (VIAC) in the midtrimester of pregnancy. J Matern Fetal Neonatal Med 25: 2002-2013.

Getahun D, Ananth CV, Selvam N, Demissie K. 2005. Adverse perinatal outcomes among interracial couples in the United States. Obstet Gynecol 106: 81-88.

Gibb W. 1998. The role of prostaglandins in human parturition. Ann Med 30: 235-241.

Gurevich P, Elhayany A, Ben-Hur H, Moldavsky M, Szvalb S, Zandbank J, Shperling I, Zusman I. 2003. An immunohistochemical study of the secretory immune system in human fetal membranes and decidua of the first trimester of pregnancy. Am J Reprod Immunol 50: 13-19.

Hansen PJ, Bazer FW, Segerson EC Jr. 1986. Skin graft survival in the uterine lumen of ewes treated with progesterone. Am J Reprod Immunol Microbiol 12: 48-54.

Harper LM, Parry S, Stamilio DM, Odibo AO, Cahill AG, Strauss JF III, Macones GA. 2012. The interaction effect of bacterial vaginosis and periodontal disease on the risk of preterm delivery. Am J Perinatol 29: 347-352.

Hickey DK, Patel MV, Fahey JV, Wira CR. 2011. Innate and adaptive immunity at mucosal surfaces of the female reproductive tract: Stratification and integration of immune protection against the transmission of sexually transmitted infections. J Reprod Immunol 88: 185-194.

Hirota Y, Daikoku T, Tranguch S, Xie H, Bradshaw HB, Dey SK. 2010. Uterine-specific p53 deficiency confers premature uterine senescence and promotes preterm birth in mice. J Clin Invest 120: 803-815.

Hirota Y, Cha J, Yoshie M, Daikoku T, Dey SK. 2011. Heightened uterine mammalian target of rapamycin complex 1 (mTORC1) signaling provokes preterm birth in mice. Proc Natl Acad Sci 108: 18073-18078.

Hoang M, Potter JA, Gysler SM, Han CS, Guller S, Norwitz ER, Abrahams VM. 2014. Human fetal membranes generate distinct cytokine profiles in response to bacterial 
E.R. Norwitz et al.

Toll-like receptor and Nod-like receptor agonists. Biol Reprod 90: 39.

Husslein P, Fuchs A-R, Fuchs F. 1981. Oxytocin and the initiation of human parturition. I: Prostaglandin release during induction of labor with oxytocin. Am J Obstet Gynecol 141: 688-693.

Iams JD, Goldenberg RL, Mercer BM, Moawad A, Thom E, Meis PJ, McNellis D, Caritis SN, Miodovnik M, et al. 1998. The Preterm Prediction Study: Recurrence risk of spontaneous preterm birth. Am J Obstet Gynecol 178: 1035-1040.

Iams JD, Cebrik D, Lynch C, Behrendt N, Das A. 2011. The rate of cervical change and the phenotype of spontaneous preterm birth. Am J Obstet Gynecol 205: 130.e1-130.e6.

Ilievski V, Hirsch E. 2010. Synergy between viral and bacterial Toll-like receptors leads to amplification of inflammatory responses and preterm labor in the mouse. Biol Reprod 83: 767-773.

Jakobsen TR, Clausen FB, Rode L, Dziegiel MH, Tabor A. 2012. High levels of fetal DNA are associated with increased risk of spontaneous preterm delivery. Prenat Diagn 32: $840-845$.

Jaschevatzky OE, Shalit A, Grunstein S, Kaplanski J, Danon A. 1983. Increased decidual prostaglandin E concentration in human abortion. Br J Obstet Gynaecol 90: 958 960.

Jiang TT, Chaturvedi V, Ertelt JM, Kinder JM, Clark DR, Valent AM, Xin L, Way SS. 2014. Regulatory T cells: New keys for further unlocking the enigma of fetal tolerance and pregnancy complications. J Immunol 192 4949-4956.

Kalantaridou SN, Zoumakis E, Weil S, Lavasidis LG, Chrousos GP, Makrigiannakis A. 2007. Reproductive corticotropin releasing hormone, implantation, and fetal immunotolerance. Crit Rev Clin Lab Sci 44: 461-481.

Kao LC, Germeyer A, Tulac S, Lobo S, Yang JP, Taylor RN, Osteen K, Lessey BA, Giudice LC. 2003. Expression profiling of endometrium from women with endometriosis reveals candidate genes for disease-based implantation failure and infertility. Endocrinology 144: 2870-2881.

Keirse MJNC, Turnbull AC. 1973. E prostaglandins in amniotic fluid during late pregnancy and labour. $J$ Obstet Gynaecol Br Commonw 80: 970-973.

Kim J, Stirling KJ, Cooper ME, Ascoli M, Momany AM, McDonald EL, Ryckman KK, Rhea L, Schaa KL, Cosentino $\mathrm{V}$, et al. 2013. Sequence variants in oxytocin pathway genes and preterm birth: A candidate gene association study. BMC Med Genet 14: 77.

King J, Flenady V, Cole S, Thornton S. 2005. Cyclo-oxygenase (COX) inhibitors for treating preterm labour. $\mathrm{Co}$ chrane Database Syst Rev (2): CD001992.

King AE, Kelly RW, Sallenave JM, Bocking AD, Challis JR. 2007. Innate immune defenses in the human uterus during pregnancy. Placenta 28: 1099-1106.

Klebanoff MA, Carey JC, Hauth JC, Hillier SL, Nugent RP, Thom EA, Ernest JM, Heine RP, Wapner RJ, Trout W, et al. 2001. Failure of metronidazole to prevent preterm delivery among pregnant women with asymptomatic Trichomonas vaginalis infection. $N$ Engl $J$ Med 345: 487-493.
Koga K, Cardenas I, Aldo P, Abrahams VM, Peng B, Fill S, Romero R, Mor G. 2009. Activation of TLR3 in the trophoblast is associated with preterm delivery. Am J Reprod Immunol 61: 196-212.

Kruse A, Hallmann R, Butcher EC. 1999a. Specialized patterns of vascular differentiation antigens in the pregnant mouse uterus and the placenta. Biol Reprod 61: 13931401.

Kruse A, Merchant MJ, Hallmann R, Butcher EC. 1999b. Evidence of specialized leukocyte-vascular homing interactions at the maternal/fetal interface. Eur J Immunol 29: 1116-1126.

Kruse A, Martens N, Fernekorn U, Hallmann R, Butcher EC. 2002. Alterations in the expression of homing-associated molecules at the maternal/fetal interface during the course of pregnancy. Biol Reprod 66: 333-345.

Lamont RF, Nhan-Chang CL, Sobel JD, Workowski K, Conde-Agudelo A, Romero R. 2011. Treatment of abnormal vaginal flora in early pregnancy with clindamycin for the prevention of spontaneous preterm birth: A systematic review and metaanalysis. Am J Obstet Gynecol 205: 177190.

Lessey BA, Lebovic DI, Taylor RN. 2013. Eutopic endometrium in women with endometriosis: Ground zero for the study of implantation defects. Semin Reprod Med 31: 109-124.

Lissauer D, Piper K, Goodyear O, Kilby MD, Moss PA. 2012. Fetal-specific $\mathrm{CD}^{+}$cytotoxic $\mathrm{T}$ cell responses develop during normal human pregnancy and exhibit broad functional capacity. J Immunol 189: 1072-1080.

Lo YM, Tein MS, Lau TK, Haines CJ, Leung TN, Poon PM, Wainscoat JS, Johnson PJ, Chang AM, Hjelm NM. 1998. Quantitative analysis of fetal DNA in maternal plasma and serum: Implications for noninvasive prenatal diagnosis. Am J Hum Genet 62: 768-775.

Lockwood CJ, Kuczynski E. 2001. Risk stratification and pathological mechanisms in preterm delivery. Paediatr Perinat Epidemiol 15: S78-S89.

MacDonald PC, Koga S, Casey ML. 1991. Decidual activation in parturition: Examination of amniotic fluid for mediators of the inflammatory response. Ann NY Acad Sci 622: 315-330.

Macones GA, Parry S, Elkousy M, Clothier B, Ural SH, Strauss JF. 2004. A polymorphism in the promoter region of TNF and bacterial vaginosis: Preliminary evidence of gene-environment interaction in the etiology of spontaneous preterm birth. Am J Obstet Gynecol 190: $1504-$ 1508.

Macones GA, Parry S, Nelson DB, Strauss JF, Ludmir J, Cohen AW, Stamilio DM, Appleby D, Clothier B, Sammel MD, et al. 2010. Treatment of localized periodontal disease in pregnancy does not reduce the occurrence of preterm birth: Results from the Periodontal Infections and Prematurity Study (PIPS). Am J Obstet Gynecol 202: 147.e1-148.e8.

Matzinger P, Kamala T. 2011. Tissue-based class control: The other side of tolerance. Nat Rev Immunol 11: 221-230.

McLean M, Bisits A, Davies J, Woods R, Lowry P, Smith R. 1995. A placental clock controlling the length of human pregnancy. Nat Med 1: 460-463.

Menon R, Velez DR, Thorsen P, Vogel I, Jacobsson B, Williams SM, Fortunato SJ. 2006. Ethnic differences in key 
candidate genes for spontaneous preterm birth: TNF- $\alpha$ and its receptors. Hum Hered 62: 107-118.

Menon R, Boldogh I, Hawkins HK, Woodson M, Polettini J, Syed TA, Fortunato SJ, Saade GR, Papaconstantinou J, Taylor RN. 2014. Histological evidence of oxidative stress and premature senescence in preterm premature rupture of the human fetal membranes recapitulated in vitro. Am J Pathol 184: 1740-1751.

Mercer BM, Goldenberg RL, Moawad AH, Meis PJ, Iams JD, Das AF, Caritis SN, Miodovnik M, Menard MK, et al. 1999. The preterm prediction study: Effect of gestational age and cause of preterm birth on subsequent obstetric outcome. Am J Obstet Gynecol 181: 1216-1221.

Mitsunaga F, Ueiwa M, Kamanaka Y, Morimoto M, Nakamura S. 2010. Fetal sex determination of macaque monkeys by a nested PCR using maternal plasma. Exp Anim 59: $255-260$.

Moffett JR, Aryan Namboodiri MA. 2003. Tryptophan and the immune response. Immunol Cell Biol 81: 247-265.

Mor G, Abrahams VM. 2013. The Immunology of Pregnancy. In: Creasy and Resnik's maternal-fetal medicine, 7th edition (ed. Creasy R, Resnik R, et al.), pp. 80-92. Elsevier-Saunders, Philadelphia.

Muglia LJ. 2000. Genetic analysis of fetal development and parturition control in the mouse. Pediatr Res 47: 437443.

Muglia LJ, Katz M. 2010. The enigma of spontaneous preterm birth. N Engl J Med 362: 529-535.

Munn DH, Zhou M, Attwood JT, Bondarev I, Conway SJ, Marshall B, Brown C, Mellor AL. 1998. Prevention of allogeneic fetal rejection by tryptophan catabolism. Science 281: 1191-1193.

Murphy SP, Fast LD, Hanna NN, Sharma S. 2005. Uterine NK cells mediate inflammation-induced fetal demise in IL-10-null mice. J Immunol 175: 4084-4090.

Murray SA, Morgan JL, Kane C, Sharma Y, Heffner CS, Lake J, Donahue LR. 2010. Mouse gestation length is genetically determined. PLoS ONE 5: e12418.

Myatt L, Chaudhuri G, Gordon D, Elder MG. 1977. Prostaglandin production by leucocytes attached to intrauterine devices. Contraception 15: 589-599.

Nancy P, Erlebacher A. 2014. T cell behavior at the maternal-fetal interface. Int J Dev Biol 58: 189-198.

Nancy P, Tagliani E, Tay CS, Asp P, Levy DE, Erlebacher A. 2012. Chemokine gene silencing in decidual stromal cells limits $\mathrm{T}$ cell access to the maternal-fetal interface. Science 336: $1317-1321$.

Nguyen DP, Genç MR, Vardhana S, Babula O, Onderdonk A, Witkin SS. 2004. Ethnic differences of polymorphisms in cytokine and innate immune system genes in pregnant women. Obstet Gynecol 104: 293-300.

Nordling C. 1953. A new theory on cancer-inducing mechanism. Br J Cancer 7: 68-72.

Norwitz ER, Wilson T. 2000. Secretory component: A potential regulator of endometrial-decidual prostaglandin production in early human pregnancy. Am J Obstet Gynecol 183: 108-117.

Norwitz ER, Starkey PM, López Bernal A. 1992. Prostaglandin D2 production by term human decidua: Cellular origins defined using flow cytometry. Obstet Gynecol 80: $440-445$.
Norwitz ER, Robinson JN, Challis JRG. 1999. The control of labor. N Engl J Med 341: 660-666.

Norwitz ER, Schust DJ, Fisher SJ. 2001. Implantation and the survival of early pregnancy. N Engl J Med 345: 14001408.

Norwitz ER, Mahendroo M, Lye SJ. 2014. Biology of Parturition. In: Creasy and Resnick's maternal-fetal medicine, 7th edition (ed. Creasy R, Resnik R, et al.), pp. 66-79. Elsevier-Saunders, Philadelphia.

Olson DM, Mijovic JE, Sadowsky DW. 1995. Control of human parturition. Semin Perinatol 19: 52-63.

Parham P, Norman PJ, Abi-Rached L, Hilton HG, Guethlein LA. 2012. Review: Immunogenetics of human placentation. Placenta 33: S71-S80.

Patel FA, Challis JRG. 2002. Cortisol progesterone antagonism in the regulation of 15-hydroxy prostaglandin dehydrogenase activity and mRNA levels in human chorion and placental trophoblast cells at term. J Clin Endocrinol Metab 87: 700-708.

Phillippe M. 2014. Cell-free fetal DNA-A trigger for parturition. N Engl J Med 370: 2534-2536.

Plunkett J, Doniger S, Morgan T, Haataja R, Hallman M, Puttonen H, Menon R, Kuczynski E, Norwitz E, Snegovskikh V, et al. 2010. Primate-specific evolution of noncoding element insertion into PLA2G4C and human preterm birth. BMC Med Genomics 3: 62.

Plunkett J, Doniger S, Orabona G, Morgan T, Haataja R, Hallman M, Puttonen H, Menon R, Kuczynski E, Norwitz E, et al. 2011. An evolutionary genomic approach to identify genes involved in human birth timing. PLoS Genet 7: e1001365.

Pradeu T, Cooper EL. 2012. The danger theory: 20 years later. Front Immunol 3: 287.

Racicot K, Cardenas I, Wünsche V, Aldo P, Guller S, Means RE, Romero R, Mor G. 2013. Viral infection of the pregnant cervix predisposes to ascending bacterial infection. J Immunol 191: 934-941.

Redman CW, Sargent IL. 2010. Immunology of pre-eclampsia. Am J Reprod Immunol 63: 534-543.

Robertson SA, Moldenhauer LM. 2014. Immunological determinants of implantation success. Int J Dev Biol 58: 205-217.

Robertson SA, Skinner RJ, Care AS. 2006. Essential role for IL-10 in resistance to lipopolysaccharide-induced preterm labor in mice. J Immunol 177: 4888-4896.

Robertson SA, Guerin LR, Moldenhauer LM, Hayball JD. 2009. Activating T regulatory cells for tolerance in early pregnancy-The contribution of seminal fluid. J Reprod Immunol 83: 109-116.

Romero R, Munoz H, Gomez R, Parra M, Polanco M, Valverde V, Hasbun J, Garrido J, Ghezzi F, Mazor M, et al. 1996. Increase in prostaglandin bioavailability precedes the onset of human parturition. Prostaglandins Leukot Essent Fatty Acids 54: 187-191.

Romero R, Dey SK, Fisher SJ. 2014. Preterm labor: One syndrome, many causes. Science 345: 760-765.

Saito S, Shima T, Inada K, Nakashima A. 2013. Which types of regulatory $\mathrm{T}$ cells play important roles in implantation and pregnancy maintenance? Am J Reprod Immunol 69: $340-345$. 
E.R. Norwitz et al.

Sandman CA, Glynn L, Schetter CD, Wadhwa P, Garite T, Chicz-DeMet A, Hobel C. 2006. Elevated maternal cortisol early in pregnancy predicts third trimester levels of placental corticotrophin releasing hormone (CRH): Priming the placental clock. Peptides 27: 1457-1463.

Scharfe-Nugent A, Corr SC, Carpenter SB, Keogh L, Doyle B, Martin C, Fitzgerald KA, Daly S, O'Leary JJ, O’Neill LA. 2012. TLR9 provokes inflammation in response to fetal DNA: Mechanism for fetal loss in preterm birth and preeclampsia. J Immunol 188: 5706-5712.

Schjenken JE, Robertson SA. 2014. Seminal fluid and immune adaptation for pregnancy-Comparative biology in mammalian species. Reprod Domest Anim 49: 27-36.

Schulte MM, Tsai J, Moley KH. 2015. Obesity and PCOS: The effect of metabolic derangements on endometrial receptivity at the time of implantation. Reprod Sci 22: 6-14.

Sebire NJ. 2001. Choriodecidual inflammation syndrome (CoDIS) is the leading, and under recognised, cause of early preterm delivery and second trimester miscarriage. Med Hypothesis 56: 497-500.

Shaw JL, Horne AW. 2012. The paracrinology of tubal ectopic pregnancy. Mol Cell Endocrinol 358: 216-222.

Shaw JL, Fitch P, Cartwright J, Entrican G, Schwarze J, Critchley HO, Horne AW. 2011. Lymphoid and myeloid cell populations in the non-pregnant human Fallopian tube and in ectopic pregnancy. J Reprod Immunol 89: 84-91.

Shepard MT, Bonney EA. 2013. PD-1 regulates T cell proliferation in a tissue and subset specific manner during normal mouse pregnancy. Immunol Invest 42: 385-408.

Silasi M, Mor G. 2012. Decidual stromal cells as regulators of T-cell access to the maternal-fetal interface. Am J Reprod Immunol 68: 279-281.

Stout MJ, Conlon B, Landeau M, Lee I, Bower C, Zhao Q, Roehl KA, Nelson DM, Macones GA, Mysorekar IU. 2013. Identification of intracellular bacteria in the basal plate of the human placenta in term and preterm gestations. Am J Obstet Gynecol 208: 226.e1-226.e7.

Subramaniam A, Abramovici A, Andrews WW, Tita AT. 2012. Antimicrobials for preterm birth prevention: An overview. Infect Dis Obstet Gynecol 2012: 157159.

Sun Y, Qin X, Shan B, Wang W, Zhu Q, Sharma S, Wu J, Lin Y. 2013. Differential effects of the CpG-Toll-like receptor 9 axis on pregnancy outcome in nonobese diabetic mice and wild-type controls. Fertil Steril 99: 1759-1767.

Svensson AC, Sandin S, Cnattingius S, Reilly M, Pawitan Y, Hultman CM, Lichtenstein P. 2009. Maternal effects for preterm birth: A genetic epidemiologic study of 630,000 families. Am J Epidemiol 170: 1365-1372.

Tagliani E, Erlebacher A. 2011. Dendritic cell function at the maternal-fetal interface. Expert Rev Clin Immunol 7: 593-602.

Thaxton JE, Romero R, Sharma S. 2009. TLR9 activation coupled to IL-10 deficiency induces adverse pregnancy outcomes. J Immunol 183: 1144-1154.

Trowsdale J, Betz AG. 2006. Mother's little helpers: Mechanisms of maternal-fetal tolerance. Nat Immunol 7: 241 246.
Uchide N, Ohyama K, Bessho T, Takeichi M, Toyoda H. 2012. Possible roles of proinflammatory and chemoattractive cytokines produced by human fetal membrane cells in the pathology of adverse pregnancy outcomes associated with influenza virus infection. Mediators Inflamm 2012: 270670.

Uzun A, Dewan AT, Istrail S, Padbury JF. 2013. Pathwaybased genetic analysis of preterm birth. Genomics 101: $163-170$.

Varner MW, Esplin MS. 2005. Current understanding of genetic factors in preterm birth. Br J Obstet Gynaecol 112: $\mathrm{S} 28-\mathrm{S} 31$.

Ventura SJ, Bachrach CA. 2000. Nonmarital childbearing in the United States, 1940-99. Natl Vital Stat Rep 48: $1-40$.

Vince GS, Starkey PM, Jackson MC, Sargent IL, Redman CW. 1990. Flow cytometric characterisation of cell populations in human pregnancy decidua and isolation of decidual macrophages. J Immunol Methods 132: 181189.

Wadhwa PD, Culhane JF, Rauh V, Barve SS, Hogan V, Sandman CA, Hobel CJ, Chicz-DeMet A, Dunkel-Schetter C, Garite TJ, et al. 2001. Stress, infection and preterm birth: A biobehavioural perspective. Pediatr Perinat Epidemiol 15: S17-S29.

Wang H, Hirsch E. 2003. Bacterially-induced preterm labor and regulation of prostaglandin-metabolizing enzyme expression in mice: The role of toll-like receptor 4. Biol Reprod 69: 1957-1963.

Winkvist A, Mogren I, Hogberg U. 1998. Familial patterns in birth characteristics: Impact on individual and population risks. Int J Epidemiol 27: 248-254.

Wira CR, Patel MV, Ghosh M, Mukura L, Fahey JV. 2011. Innate immunity in the human female reproductive tract: Endocrine regulation of endogenous antimicrobial protection against HIV and other sexually transmitted infections. Am J Reprod Immunol 65: 196-211.

Wu HX, Jin LP, Xu B, Liang SS, Li DJ. 2014. Decidual stromal cells recruit Th17 cells into decidua to promote proliferation and invasion of human trophoblast cells by secreting IL-17. Cell Mol Immunol 11: 253-262.

Xin L, Ertelt JM, Rowe JH, Jiang TT, Kinder JM, Chaturvedi V, Elahi S, Way SS. 2014. Cutting edge: Committed Th1 $\mathrm{CD}^{+} \mathrm{T}$ cell differentiation blocks pregnancy-induced Foxp3 expression with antigen-specific fetal loss. J Immunol 192: 2970-2974.

Xiong M, Lu J, Zhao A, Xu L, Bao S, Lin Q, Yang B. 2010. Therapy with FasL-gene-modified dendritic cells confers a protective microenvironment in murine pregnancy. Fertil Steril 93: 2767-2769.

Zeeman GG, Khan-Dawood FS, Dawood MY. 1997. Oxytocin and its receptor in pregnancy and parturition: Current concepts and clinical implications. Obstet Gynecol 89: $873-883$.

Zhang J, Chen Z, Smith GN, Croy BA. 2011. Natural killer cell-triggered vascular transformation: Maternal care before birth? Cell Mol Immunol 8: 1-11. 


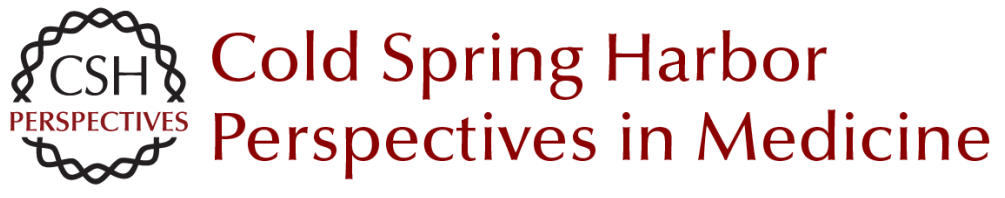

\section{Molecular Regulation of Parturition: The Role of the Decidual Clock}

Errol R. Norwitz, Elizabeth A. Bonney, Victoria V. Snegovskikh, Michelle A. Williams, Mark Phillippe, Joong Shin Park and Vikki M. Abrahams

Cold Spring Harb Perspect Med 2015; doi: 10.1101/cshperspect.a023143 originally published online April 27, 2015

Subject Collection Molecular Approaches to Reproductive and Newborn Medicine

Intergenerational Transfer of Epigenetic

Information in Sperm

Oliver J. Rando

Effects of Maternal Obesity on Fetal

Programming: Molecular Approaches

Caterina Neri and Andrea G. Edlow

The Neonatal Salivary Transcriptome Jill L. Maron

The Role of Hox Genes in Female Reproductive Tract Development, Adult Function, and Fertility Hongling Du and Hugh S. Taylor

Molecular Cross-Talk at the Feto-Maternal Interface

Gendie E. Lash

Molecular Regulation of Parturition: A Myometrial Perspective

Nora E. Renthal, Koriand'r C. Williams, Alina P. Montalbano, et al.

Genome-Wide Sequencing for Prenatal Detection of Fetal Single-Gene Disorders

Ignatia B. Van den Veyver and Christine M. Eng

MicroRNA in Ovarian Biology and Disease

Lynda K. McGinnis, Lacey J. Luense and Lane K.

Christenson
A Molecular Perspective on Procedures and

Outcomes with Assisted Reproductive

Technologies

Monica A. Mainigi, Carmen Sapienza, Samantha

Butts, et al.

Whole-Exome Sequencing and Whole-Genome

Sequencing in Critically III Neonates Suspected to Have Single-Gene Disorders

Laurie D. Smith, Laurel K. Willig and Stephen F. Kingsmore

Noninvasive Antenatal Determination of Fetal

Blood Group Using Next-Generation Sequencing

Klaus Rieneck, Frederik Banch Clausen and

Morten Hanefeld Dziegiel

Potential Uses and Inherent Challenges of Using

Genome-Scale Sequencing to Augment Current

Newborn Screening

Jonathan S. Berg and Cynthia M. Powell

Molecular Regulation of Parturition: The Role of the Decidual Clock

Errol R. Norwitz, Elizabeth A. Bonney, Victoria V.

Snegovskikh, et al.

Molecular Mechanisms of Preeclampsia

Tammy Hod, Ana Sofia Cerdeira and S. Ananth

Karumanchi

Noninvasive Prenatal Screening for Genetic

Diseases Using Massively Parallel Sequencing of

Maternal Plasma DNA

Lyn S. Chitty and Y. M. Dennis Lo

Confrontation, Consolidation, and Recognition:

The Oocyte's Perspective on the Incoming Sperm David Miller

For additional articles in this collection, see http://perspectivesinmedicine.cshlp.org/cgi/collection/ 